AgNIESZKA SKALA

Politechnika Warszawska, Polska - Warsaw University of Technology, Poland

\title{
Badanie efektywności programów edukacyjnych w zakresie przedsiębiorczości na podstawie studium przypadku Politechniki Warszawskiej - komunikat z badań
}

\author{
The Effectiveness of Educational Programs in Entrepreneurship, Based on a Case Study \\ of the Warsaw University of Technology - Statement of the Research
}

\begin{abstract}
Streszczenie: Od około dekady podejmowane są w Polsce coraz liczniejsze inicjatywy w zakresie nauczania przedsiębiorczości, także na uczelniach wyższych (w tym technicznych). W literaturze przedmiotu edukacja przedsiębiorczości jest tematem dobrze rozpoznanym, zwłaszcza pod kątem projektowania programów nauczania. Istnieje jednak luka w wiedzy o efektywności programów edukacyjnych w zakresie przedsiębiorczości, a przeprowadzenie badań pod tym kątem stanowi wyzwanie pod względem metodycznym. Głównym celem badań omówionych w artykule jest stworzenie i przetestowanie autorskiego kwestionariusza umożliwiającego weryfikację programu edukacyjnego w zakresie przedsiębiorczości i stanowiącego podstawę dla przeprowadzenia długoletnich, porównywalnych badań w tym zakresie. Ich przedmiotem są programy edukacyjne, metody ich wdrażania oraz postawy przedsiębiorcze wykazywane przez absolwentów. Omawiany w pracy autorski program edukacyjny realizowany jest w Politechnice Warszawskiej od 2007 r., zaś obecnie podejmuje się inicjatywy służące ocenie jego wpływu na kariery zawodowe jego absolwentów. Źródłem danych dla rozważań są wyniki dwóch pilotażowych badań ankietowych przeprowadzonych na uczestnikach zajęć (studentach). Wyniki te pozwoliły wstępnie określić strukturę badania właściwego i brzmienie pytań oraz sugerowanych odpowiedzi. Obecnie ankieta jest podzielona na cztery części: ocenę zajęć, badanie stosunku do samozatrudnienia, ocenę szans i zagrożeń związanych z prowadzeniem firmy oraz określenie uwarunkowań rodzinnych. Z pewnością brakuje jeszcze sposobu na uchwycenie efektów edukacji w postaci przejawiania inicjatyw ambitnych, szczególnie cennych. Na tym aspekcie będą skoncentrowane dalsze poszukiwania i badania.
\end{abstract}

\begin{abstract}
For about a decade more and more initiatives of teaching entrepreneurship are held in Poland, including universities courses (within technical ones as well). In the subject literature, teaching entrepreneurship is a well-recognized topic, especially when it comes to creating a syllabus. Nevertheless, there is a knowledge gap in the effectiveness of such entrepreneurship courses and conducting a study in this area appears to be challenging due to methodological obstacles. The main goal of the study that is discussed in this article is creating and testing a survey which enables verifying the education programs in terms of entrepreneurship. It will be a base for conducting a long-term comparison study in the area of entrepreneurship in education. The examined topics are: educational programs, methods of implementation and entrepreneurship approaches demonstrated by students. The copyrighted program discussed
\end{abstract}


in this paper takes place in the Warsaw University of Technology since 2007. Currently, there are actions to evaluate the influence of the program on careers of the University's graduates. The data source was built on the results of two pilot surveys conducted on the course participants (students). The results allowed for determining a primary structure of the main study, the tone of questions and suggested answers. Currently, the survey is divided into four parts: course evaluation, exploring the will and attitude to self-employment, examining the opportunities and threats of owning a company and defining family determinants. It is certain that there is still a difficulty to capture the effects of education in undertaking ambitious and high-growing ventures. Further research and studies will focus on this aspect.

Słowa kluczowe: edukacja; efektywność; kwestionariusz; przedsiębiorczość; szkolnictwo wyższe; weryfikacja

Key words: education; effectiveness; entrepreneurship; higher education; questionnaire; verification

Otrzymano: 23 listopada 2015

Received: 23 November 2015

Zaakceptowano: 10 marca 2016

Accepted: 10 March 2016

\section{Sugerowana cytacja/Suggested citation:}

Skala, A., Badanie efektywności programów edukacyjnych w zakresie przedsiębiorczości na podstawie studium przypadku Politechniki Warszawskiej - komunikat z badań. Przedsiębiorczość Edukacja, 12, 364-377.

\section{Wstęp}

Edukacja w zakresie przedsiębiorczości zdobywa kolejne przyczółki w polskim systemie kształcenia, zwłaszcza na poziomie szkół ponadgimnazjalnych oraz uczelni wyższych. W literaturze przedmiotu przybywa zarówno pochwalnych, jak i krytycznych publikacji omawiających kolejne inicjatywy w tym zakresie (Gabała, 2005; Feliniak, 2007; Cieślik i in.. 2011; Richert-Kaźmierska, 2011; Wach, 2013; Skala, 2015), a każdy głos w tej sprawie przyczynia się do kumulacji wiedzy i doświadczeń dydaktycznych, z których mogą czerpać kolejni edukatorzy. Równocześnie stosunkowo krótki okres wdrażania programów edukacyjnych w zakresie przedsiębiorczości powoduje, że temat weryfikacji ich skuteczności jest w tych rozważaniach, jak dotąd, właściwie nieobecny. Chodzi tutaj z jednej strony o optymalny (w funkcji celu) dobór metod nauczania, z drugiej strony - o zbadanie faktycznego wpływu uczestniczenia w zajęciach z przedsiębiorczości na losy zawodowe absolwentów. Splot badań nad oboma wymienionymi czynnikami pozwoliłby wyciągnąć wnioski dotyczące efektywności zastosowanych metod kształcenia na przyszłe postawy przedsiębiorcze (Marszałek, 2012). Pod koniec lat 90. ubiegłego stulecia W. Strykowski pisał, że zaprojektowanie modelu systemu kształcenia nie kończy procesu tworzenia go i że musi nastąpić jego empiryczna weryfikacja, czyli sprawdzenie, w jakim stopniu realizuje on założone cele (Strykowski, 1997). Niniejszy artykuł jest komunikatem z długoterminowych badań podjętych w celu wypełnienia tej luki.

Problemem badawczym postawionym w artykule jest zaplanowanie badań weryfikujących skuteczność edukacji w zakresie przedsiębiorczości na uczelni wyższej. Przedmiotem badań są programy edukacyjne, metody ich wdrażania oraz sami studenci - słuchacze. Badania te mają charakter wieloletni. Omawiany w pracy autorski program edukacyjny jest realizowany w Politechnice Warszawskiej od 2007 r., zaś obecnie podejmuje się inicjatywy służące ocenie jego wpływu na kariery zawodowe jego absolwentów. Źródłem danych dla badań przedstawionych 
w drugiej części pracy są wyniki pilotażowych badań ankietowych przeprowadzonych na uczestnikach zajęć (studentach).

W pierwszej części pracy zostanie dokonany przegląd literatury poświęconej edukacji przedsiębiorczości w kontekście problemu badawczego, czyli badania skuteczności programów edukacyjnych. W drugiej części zostaną przedstawione założenia realizacji ośmioletniego programu edukacyjnego wdrażanego w Politechnice Warszawskiej. Następnie zostaną omówione struktury i wyniki pilotażowych badań służących weryfikacji efektów tego programu oraz zostanie przedstawiona propozycja dalszych działań w tym zakresie.

\section{Przegląd literatury}

Edukacja przedsiębiorczości to jeden z kluczowych elementów ekosystemu promocji i wspierania przedsiębiorczości (Kuratko, 2005), także w Polsce (Wach, 2013). Badania A. Charneya i G.D. Libecapa dowiodły, że studenci wykształceni w kierunku przedsiębiorczości są nie tylko bardziej skłonni do zakładania własnych firm, lecz również częściej znajdują zatrudnienie w firmach szybko rozwijających się (high-growing) lub realizują ważne projekty związane z rozwojem nowych produktów w ramach większych organizacji (Charney, Libecap, 2000). To ważny trop w kontekście badania efektywności programów edukacyjnych w zakresie przedsiębiorczości.

A. Kuckertz z kolei podkreśla znaczenie celu, który stawia się przed edukacją przedsiębiorczości: czy ma ona doprowadzić do tego, aby student w ogóle został przedsiębiorcą, czy do tego, by był „lepszym” przedsiębiorcą (jeśli już nim zostanie) (Kuckertz, 2011). Ten rodzaj pytań jest obecnie jednym z głównych nurtów badań, zwłaszcza w kontekście pracy, której autorami są M. Henrekson i T. Sanandaji. Uczeni ci stawiają wyraźny podział między przedsiębiorczością rozumianą jako samozatrudnienie a przedsiębiorczością „schumpeterowską”, tj. generującą znaczący wzrost bogactwa i zatrudnienia. Zastanawiają się też nad czynnikami wzmagającymi tendencję do rozwoju jednej lub drugiej (Henrekson, Sanandaji, 2014).

W poglądowej pracy na temat miejsca przedsiębiorczości w edukacji Z. Zioło zwraca uwagę na potrzebę holistycznego kształtowania postaw przedsiębiorczych w edukacji szkolnej i akademickiej, a także na konieczność dostosowania celów tej edukacji do potrzeb nowoczesnego rynku pracy (Zioło, 2012). Z kolei K. Wach argumentuje, że celem nauczania przedsiębiorczości jest promowanie kreatywności, innowacji i samozatrudnienia (Wach, 2013). Idąc tropem Henreksona i Sanandajiego, sam fakt podjęcia samozatrudnienia przez absolwenta nie powinien być jednak traktowany jako sukces, a dopiero tworzenie firm, które charakteryzują się wysoką stopą wzrostu i nowatorskimi wdrożeniami. O wskazówkach dla edukacji traktują też ostatnie prace J. Cieślika. Wymienia on szkodliwe „iluzje” w postrzeganiu zjawiska przedsiębiorczości, których powielanie w procesie edukacyjnym może prowadzić do powtarzania błędów w przyszłości i skutkować niepowodzeniem prób przedsiębiorczych (Cieślik, 2014a, 2014b).

Odnosząc się do drugiego nurtu poświęconego metodologii nauczania, Kucketz podkreśla konieczność zrozumienia i wdrożenia nowej, „trzeciej misji” na uniwersytetach (obok nauki i dydaktyki), polegającej na wytworzeniu całościowej kultury przedsiębiorczości (Kucketz, 2013). W podobnym tonie utrzymują się publikacje Cieślika sprzed kilku lat, opierające się na doświadczeniach z wdrożeń programów edukacyjnych, w tym też na polskich uczelniach (Cieślik, 2008; Cieślik i in., 2011). 
K. Wach zwraca uwagę na fakt, że program nauczania przedsiębiorczości powinien zawierać takie elementy, jak: rozwijanie cech i umiejętności przedsiębiorczych i realizowanie projektów biznesowych (Wach, 2013). Dobrym przykładem są tutaj prace S. Blanka, E. Reisa i A. Osterwaldera, którzy wspólnie stworzyli filozofię i zestaw narzędzi do zarządzania i edukowania, tzw. Lean Startup (Blank, 2013; Blank, Dorf, 2012; Ries, 2011; Osterwalder, 2010). W tabeli 1 przedstawiono wybrane pozycje literatury dotyczące edukacji przedsiębiorczości wraz z krótką notą o najważniejszych wnioskach zawartych w tych publikacjach.

Tab. 1. Wybrane pozycje literatury dotyczące edukacji przedsiębiorczości

\begin{tabular}{|c|c|}
\hline Pozycja literatury & Najważniejsze wnioski \\
\hline $\begin{array}{l}\text { Kuratko, D. (2005). The Emergence of } \\
\text { Entrepreneurship Education: Development, } \\
\text { Trends and Challenges }\end{array}$ & $\begin{array}{l}\text { Holistyczne ujęcie tematu edukacji } \\
\text { przedsiębiorczości: geneza, cele, rozwój, } \\
\text { metodyka. }\end{array}$ \\
\hline \begin{tabular}{|l|} 
Fayolle, A. i Lassas-Clerc (2006). Essay on the \\
Nature of Entrepreneurship Education
\end{tabular} & Przedsiębiorczość MOŻE być nauczana. \\
\hline $\begin{array}{l}\text { Katz, J.A.(2003). The chronology and intellectual } \\
\text { tracectory of American entrepreneurship } \\
\text { education }\end{array}$ & $\begin{array}{l}\text { Chronologiczny rozwój metod edukacji } \\
\text { przedsiębiorczości w USA. }\end{array}$ \\
\hline $\begin{array}{l}\text { Gibb, A.A.(1993). Entreprise culture and } \\
\text { education (...) }\end{array}$ & $\begin{array}{l}\text { Nauczanie klasyczne vs. nauczanie } \\
\text { przedsiębiorcze, studium metodyczne. }\end{array}$ \\
\hline $\begin{array}{l}\text { Kuckertz, A.(2013). Entrepreneurship Education- } \\
\text { status quo and prospective developments }\end{array}$ & $\begin{array}{l}\text { Przedsiębiorcze korporacje, przedsiębiorczy } \\
\text { uniwersytet, wyzwania dla edukacji. }\end{array}$ \\
\hline \begin{tabular}{|l|} 
Cieślik, J. (2008). Kształcenie w zakresie \\
przedsiębiorczości na poziomie akademickim
\end{tabular} & \multirow{2}{*}{$\begin{array}{l}\text { Koncepcje i przykłady wdrożeń kształcenia } \\
\text { w zakresie przedsiębiorczości na poziomie } \\
\text { akademickim. }\end{array}$} \\
\hline $\begin{array}{l}\text { Cieślik i in. (2011). Edukacja dla } \\
\text { przedsiębiorczości akademickiej }\end{array}$ & \\
\hline $\begin{array}{l}\text { Wach, K. (2013). Edukacja na rzecz } \\
\text { przedsiębiorczości wobec wspótczesnych wyzwań } \\
\text { cywilizacyjno-gospodarczych }\end{array}$ & $\begin{array}{l}\text { Najważniejsze komponenty edukacji } \\
\text { przedsiębiorczości: wiedza, umiejętności, } \\
\text { postawy. }\end{array}$ \\
\hline $\begin{array}{l}\text { Zioło, Z. (2012). Miejsce przedsiębiorczości } \\
\text { w edukacji }\end{array}$ & $\begin{array}{l}\text { Konieczność holistycznego kształtowania } \\
\text { postaw przedsiębiorczych w edukacji szkolnej } \\
\text { i akademickiej oraz dostosowania celów tej } \\
\text { edukacji do potrzeb nowoczesnego rynku pracy. }\end{array}$ \\
\hline $\begin{array}{l}\text { Blank, S. (2013). Why the Lean Startup Changes } \\
\text { Everything? }\end{array}$ & $\begin{array}{l}\text { Lean Startup jako nowoczesna metodologia } \\
\text { zarządzania startupem i zarazem edukacji } \\
\text { w tym zakresie. }\end{array}$ \\
\hline $\begin{array}{l}\text { Charney i Libecap (2000). Impact of } \\
\text { entrepreneurship education }\end{array}$ & $\begin{array}{l}\text { Wykształceni w kierunku przedsiębiorczości } \\
\text { częściej znajdują zatrudnienie w firmach szybko } \\
\text { rosnących lub realizują projekty związane } \\
\text { z rozwojem nowych produktów w ramach } \\
\text { większych organizacji. }\end{array}$ \\
\hline $\begin{array}{l}\text { Henrekson i Sanandaji (2014). Small business } \\
\text { activity does not measure entrepreneurship }\end{array}$ & $\begin{array}{l}\text { Edukacja przedsiębiorczości niekoniecznie sprzyja } \\
\text { samozatrudnieniu, ale jest istotnym czynnikiem } \\
\text { determinującym ambitną przedsiębiorczość } \\
\text { w rozumieniu „schumpeterowskim”. }\end{array}$ \\
\hline
\end{tabular}

Źródło: Skala (2015) 
W odniesieniu do omówionej literatury poświęconej edukacji przedsiębiorczości sensu largo, temat metodyki i wyników badań nad efektywnością programów nauczania przedsiębiorczości właściwie nie istnieje. D. Piróg zaznacza, że „na świecie wykonano nieliczne empiryczne badania, które eksplorowałyby zagadnienie stopnia wpływu ukończenia edukacji na poziomie wyższym [niekoniecznie zawierającej elementy przedsiębiorczości - przyp. aut.] na kreowanie postaw przedsiębiorczych" (Piróg, 2014: 311), co dopiero mówić o badaniu wpływu ukończenia edukacji w zakresie przedsiębiorczości na te postawy.

W publikacji tej omawiane są wyniki badań, które koncentrują się na badaniu odsetka studentów deklarujących zainteresowanie własnym biznesem jako opcją rozwoju zawodowego pod koniec studiów i porównaniu z odsetkiem tych, którzy faktycznie podjęli takie działania w rok po ukończeniu studiów. Autorka zwraca uwagę na duży rozdźwięk między pierwszym (wysokim) wynikiem a drugim (na niskim poziomie, ok. 5-10\%). W kontekście omawianej wyżej literatury trzeba podkreślić, że badania te dotyczyły zjawiska samozatrudnienia jako przejawu przedsiębiorczości. Wydaje się, że te wyniki są efektem dość typowego rozdźwięku między postawą deklaratywną a faktyczną. Autorka upatruje też przyczyn tych różnic w deficycie kluczowych kompetencji i wskazuje odpowiednie metody kształcenia jako sposób na ich uzupełnienie. W kolejnej publikacji ta sama autorka idzie o krok dalej, ujawniając lukę w konceptualizacji samego pojęcia kompetencji z zakresu przedsiębiorczości (Piróg, 2015). Zaznacza też, że właśnie styk badań naukowych i dydaktyki w tym zakresie stwarza szansę na uzupełnienie wskazanych braków w wiedzy. Przykładem publikacji dotykających tematu badania efektywności kształcenia, choć nie dotykających nauczania w zakresie przedsiębiorczości, są prace U. Jeruszki (Jeruszka, 2001; 2006; 2011), która zajmuje się badaniem związków między kształceniem zawodowym i wyższym a losami ich absolwentów na rynku pracy.

Temat badania efektywności programów edukacyjnych w zakresie przedsiębiorczości na poziomie kształcenia wyższego jest nieobecny w polskiej literaturze - na dowód można przytoczyć fakt, że analiza dostępnych publikacji w niniejszym czasopiśmie, najwłaściwszym do publikacji tego typu prac w Polsce, nie wykazała ani jednej pracy poświęconej bezpośrednio tej tematyce. Pojawiają się, wspomniane na wstępie, cenne badania i wnioski dotyczące kształtowania programów dydaktycznych i metod edukacyjnych w zakresie przedsiębiorczości na różnych szczeblach kształcenia, ale brakuje prac poświęconych stricte metodom i wynikom badań nad ich efektywnością.

\section{Wdrożenie programów edukacyjnych w zakresie przedsiębiorczości}

Autorka niniejszego artykułu od roku $2007^{1}$ projektuje i realizuje zajęcia z przedsiębiorczości. Element oceny i weryfikacji wdrożonych programów jest na tym etapie najsłabiej rozbudowany ze względu na naturalne odroczenie w czasie efektów tej edukacji. W 2016 r. planowane jest przeprowadzenie badań w tym zakresie w odniesieniu do dużej liczby (1,4 tys.) absolwentów Politechniki Warszawskiej.

W latach 2007-2014 nastąpiła ewolucja realizowanego programu dydaktycznego w zakresie przedsiębiorczości (Skala, 2015). Wdrażane zmiany były, między innymi, pochodną procesu uczenia się, podnoszenia własnych kwalifikacji oraz doświadczeń dydaktycznych. W efekcie nastąpiły znaczące zmiany w najważniejszych pozycjach curriculum zajęć:

\footnotetext{
${ }^{1}$ W latach 2007-2011 według wzorca z programu SEIPA, od 2011 - tworząc programy samodzielnie.
} 
1. wykładowy charakter zajęć zmienił się w warsztaty projektowe (project based learning) $\mathrm{z}$ elementami wykładu - konwersatorium;

2. 5-letnie planowanie biznesowe w arkuszach kalkulacyjnych ustąpiło miejsca modelowaniu biznesowemu na podstawie kanwy modelu biznesowego (Osterwalder, Pigneur, 2010);

3. w miejsce portalu internetowego służącego jednostronnej komunikacji ze studentem i będącego repozytorium materiałów pojawiła się platforma e-learningowa wspomagająca interaktywną komunikację dwustronną;

4. poza tradycyjnym układem prowadzący-studenci część zajęć funkcjonuje obecnie w formule flipped classroom, która polega na prezentowaniu przez słuchaczy wyników prac wykonywanych między zajęciami (Herreid, 2013; Enfield, 2013). To prowadzący jest w takiej sytuacji słuchaczem i komentuje, wraz z innymi uczestnikami, wykonaną przez studentów pracę;

5. kluczowym elementem zajęć jest zderzenie koncepcji projektów rozwijanych przez studentów $\mathrm{z}$ ich potencjalnymi klientami w formule: get out of the building, czyli wdrożenie narzędzia, jakim jest tzw. customer development (Blank, 2013; Blank, Dorf, 2012);

6. w czasie zajęć dąży się do tego, aby stworzyć prototypy projektów, nad którymi pracują studenci;

7. w miejsce incydentalnych konsultacji prowadzący-zespoły pojawiły się dwie sesje mentoringowe: pierwsza w połowie zajęć, na którą zaproszeni są goście z zewnątrz (przedsiębiorcy), druga przed prezentacjami końcowymi - 20-minutowa sesja indywidualna z prowadzącą;

8. zamiast tradycyjnego zaliczenia odbywa się publiczna prezentacja projektów, na którą zapraszani są zewnętrzni goście: przedsiębiorcy i inwestorzy, a ich ocena ma wpływ na oceny końcowe z przedmiotu.

\section{Weryfikacja programu edukacyjnego w zakresie przedsiębiorczości - badanie pilotażowe studentów}

Weryfikacja efektywności programów edukacyjnych w zakresie kształtowania kompetencji i postaw przedsiębiorczych wśród studentów nie jest zadaniem łatwym - szczególnie z punktu widzenia przyjętej metody (Cohen, Manion, Morrison, 2010; Rubacha 2013). Ciekawie na ten temat wypowiadał się Strykowski (Strykowski, 1997), proponując skale szacunkowe oraz eksperyment pedagogiczny jako dwie podstawowe metody weryfikacji programu (modelu) zajęć. Pierwsza z nich pozwala ocenić elementy składowe zajęć, zaś druga - postawy (słuchaczy). „Najkorzystniejsze dla rzetelnej oceny efektywności skonstruowanych modeli jest stosowanie obu sposobów weryfikacji. Wyniki tych badań wzajemnie się uzupełniają, co pozwala wyciągnąć wnioski o charakterze optymalizacyjnym” (Strykowski, 1997: 39). Przeprowadzone przez autorkę pilotażowe badania studentów zawierają w sobie oba wymienione przez Strykowskiego elementy, zaś za metodę przyjęto ankietyzację (Gaweł, Pietrzykowski, 2015). Mają one charakter pilotażowy przed badaniem właściwym, które ma objąć:

- bieżące grupy słuchaczy - badane będą ich postawy przedsiębiorcze, a także ocena zajęć,

- absolwentów programu edukacyjnego realizowanego w Politechnice Warszawskiej w latach 2009-2012. 
Celem wykonania badań pilotażowych jest określenie właściwej konstrukcji ankiety i formy zadawanych pytań. Obie ankiety pilotażowe przeprowadzono wśród studentów studiów licencjackich (6 i 7 semestr), uczęszczających na zajęcia w wymiarze $30 \mathrm{~h}$ (jeden semestr) z przedmiotu: przedsiębiorczość innowacyjna. Zajęcia te odbyły się według zasad przedstawionych w poprzednim punkcie. Pierwsza ankieta objęła studentów po ukończeniu zajęć, druga - w pierwszym miesiącu zajęć. Aby uchwycić ewentualną zmianę, która się dokona w postawie studenta pod wpływem samych zajęć, badanie jest zaplanowane jako dwuetapowe, czyli studenci wypełniają pierwszą ankietę na początku i drugą (zredukowaną) pod koniec zajęć. Za najważniejsze elementy badania, w ślad za przestudiowaną literaturą (Piróg, 2014; Jeruszka, 2001; 2006; 2011; Strykowski, 1997), wyznaczono zbadanie:

- uwarunkowań rodzinnych,

- stosunku do własnego biznesu jako opcji na rozwój zawodowy,

- wykazywanych postaw przedsiębiorczych.

Schemat obu badań przedstawiono w tabeli 2 .

Tab. 2. Schemat badań pilotażowych

\begin{tabular}{|c|c|c|c|c|}
\hline \multirow{2}{*}{$\begin{array}{c}\text { Metoda } \\
\text { weryfikacji }\end{array}$} & \multirow{2}{*}{ Zakres badań } & \multirow{2}{*}{$\begin{array}{c}\text { Pilotaż I } \\
\mathbf{n}=27\end{array}$} & \multicolumn{2}{|c|}{$\begin{array}{l}\text { Pilotaż II } \\
\mathbf{n}=37\end{array}$} \\
\hline & & & część 1 & $\begin{array}{c}\text { część } 2 \\
\text { planowana }\end{array}$ \\
\hline \multirow{3}{*}{$\begin{array}{l}\text { Eksperyment } \\
\text { pedagogiczny }\end{array}$} & uwarunkowania rodzinne & NIE & TAK & NIE \\
\hline & $\begin{array}{l}\text { stosunek do możliwości } \\
\text { prowadzenia własnego } \\
\text { biznesu }\end{array}$ & TAK & TAK & NIE \\
\hline & postawy przedsiębiorcze & TAK & TAK & NIE \\
\hline \multirow{2}{*}{$\begin{array}{l}\text { Skale } \\
\text { szacunkowe }\end{array}$} & ocena zajęć & TAK & NIE & TAK \\
\hline & $\begin{array}{l}\text { ocena własnego } \\
\text { zaangażowania w zajęcia }\end{array}$ & TAK & NIE & TAK \\
\hline
\end{tabular}

Źródło: opracowanie własne

Poszczególne moduły badań zostały zaprojektowane następująco:

1. W odniesieniu do badania uwarunkowań rodzinnych (pkt $1 \mathrm{w}$ tabeli 2), zadawane jest jedno pytanie - o doświadczenie obserwacji osoby przedsiębiorczej wśród najbliższej rodziny. Dzięki temu będzie można zaobserwować, czy i na ile postawy przedsiębiorcze studentów są uwarunkowane wzrastaniem w środowisku przedsiębiorców. Ma to, jak wskazali Fairlie i Robb, pozytywny wpływ na kształtowanie postaw przedsiębiorczych w przyszłości, ponieważ np. dzieci przedsiębiorców częściej zakładają własny biznes, a jak już to zrobią, to osiągają lepsze wyniki (w porównaniu z założycielami osób nieobserwujących rodzinnych biznesów) (Fairlie, Robb, 2007);

2. Badając stosunek do możliwości prowadzenia swojego biznesu (pkt. 2), zadano po dwa identyczne pytania w ramach pilotażu I i w ramach pilotażu II (różny był natomiast wybór odpowiedzi i metoda ich zbierania);

3. Badając postawy przedsiębiorcze (pkt. 3) zadano jedno pytanie w ramach pilotażu I i trzy pytania w ramach pilotażu II;

4. Ocena zajęć odbyła się na podstawie 10 pytań (pilotaż I); 
5. W ramach jednego pytania studenci ocenili własne zaangażowanie w zajęcia (pilotaż I).

Pilotażowy charakter badań objawia się dużą liczbą pytań otwartych, służących poznaniu najczęściej pojawiających się spontanicznych odpowiedzi. Służy to temu, aby w kolejnych częściach kwestionariusza stosować już pytania zamknięte, co ułatwia i uwiarygodnia wyniki. Do ich analizy zastosowano podejście usystematyzowane w postaci kategoryzacji według słów kluczowych. Kompozycję pytań, technik zbierania i pomiaru odpowiedzi oraz wyniki przedstawiono w tabeli 3 .

Wyniki badań można podzielić na dwie części. Pierwsza dotyczy doświadczeń i postaw przedsiębiorczych wykazywanych przez studentów. Druga to ocena otrzymanej oferty dydaktycznej. Zaczynając od pierwszej, to na uwagę zasługuje wysoki odsetek studentów (51\%), którzy przyznali, że w najbliższym otoczeniu mają wzorce osób przedsiębiorczych, tj. związanych zawodowo z biznesem. Ponadto rezultaty badań są następujące:

- występuje duża zmienność odpowiedzi na pytanie o zainteresowanie samozatrudnieniem w zależności od sposobu udzielania i brzmienia proponowanych odpowiedzi, dlatego metoda i brzmienie pytania trzeba dopracować z myślą o badaniu właściwym;

- wśród najważniejszych obaw związanych z założeniem i prowadzeniem firmy (ryc. 1) dominuje brak szeroko rozumianej wiedzy, następnie brak pieniędzy i kontaktów biznesowych (w obu przypadkach występuje duża zmienność odpowiedzi);

- za najatrakcyjniejsze w byciu przedsiębiorcą studenci wskazują „niezależność” i „satysfakcję z bycia na swoim" (ryc. 2);

- szczególnie interesującym wynikiem badania okazały się odpowiedzi na pytanie o podejmowane przez studentów inicjatywy przedsiębiorcze. Pytanie to, po odpowiedniej modyfikacji (rozwinięciu) może pomóc w ankiecie docelowej ocenić charakter postaw przedsiębiorczych pod kątem ich innowacyjności i potencjału.

$\mathrm{W}$ odniesieniu do oceny zajęć, proponowany program edukacyjny spotkał się z bardzo dobrym przyjęciem przez studentów. Ankieta wykazała wysokie oceny dla treści i formuły zajęć oraz przygotowania prowadzącej. Występowała niewysoka zmienność odpowiedzi. Najsurowiej studenci ocenili siebie, czyli własne zaangażowanie w zajęcia: średnio na poziomie 3,85 . Konstrukcja pytań wydaje się właściwa. Kolejna ocena zajęć odbyła się w ramach drugiej części drugiego badania pilotażowego w lutym 2016 r.

Ryc. 1. Struktura odpowiedzi na pytanie o obawy związane z założeniem i prowadzeniem firmy

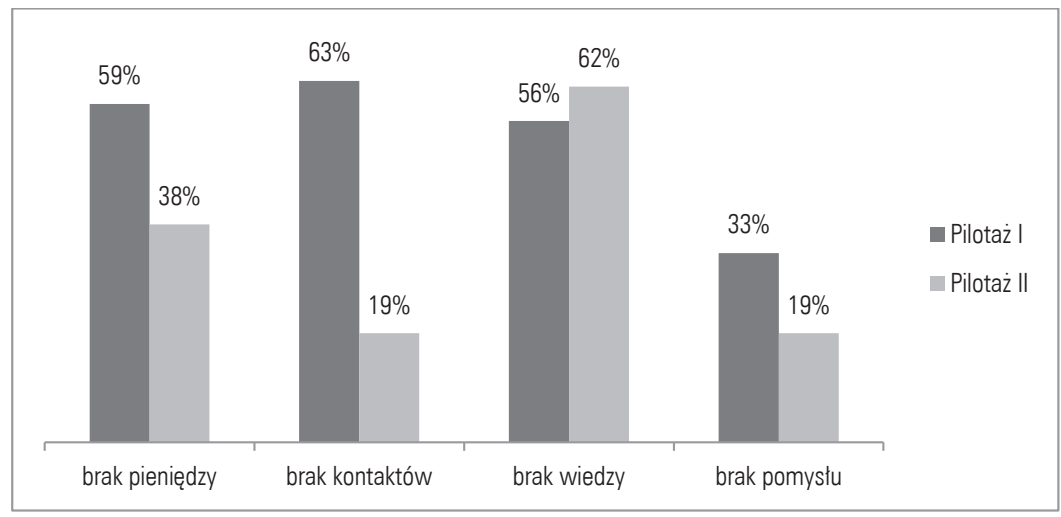

Źródło: opracowanie własne 


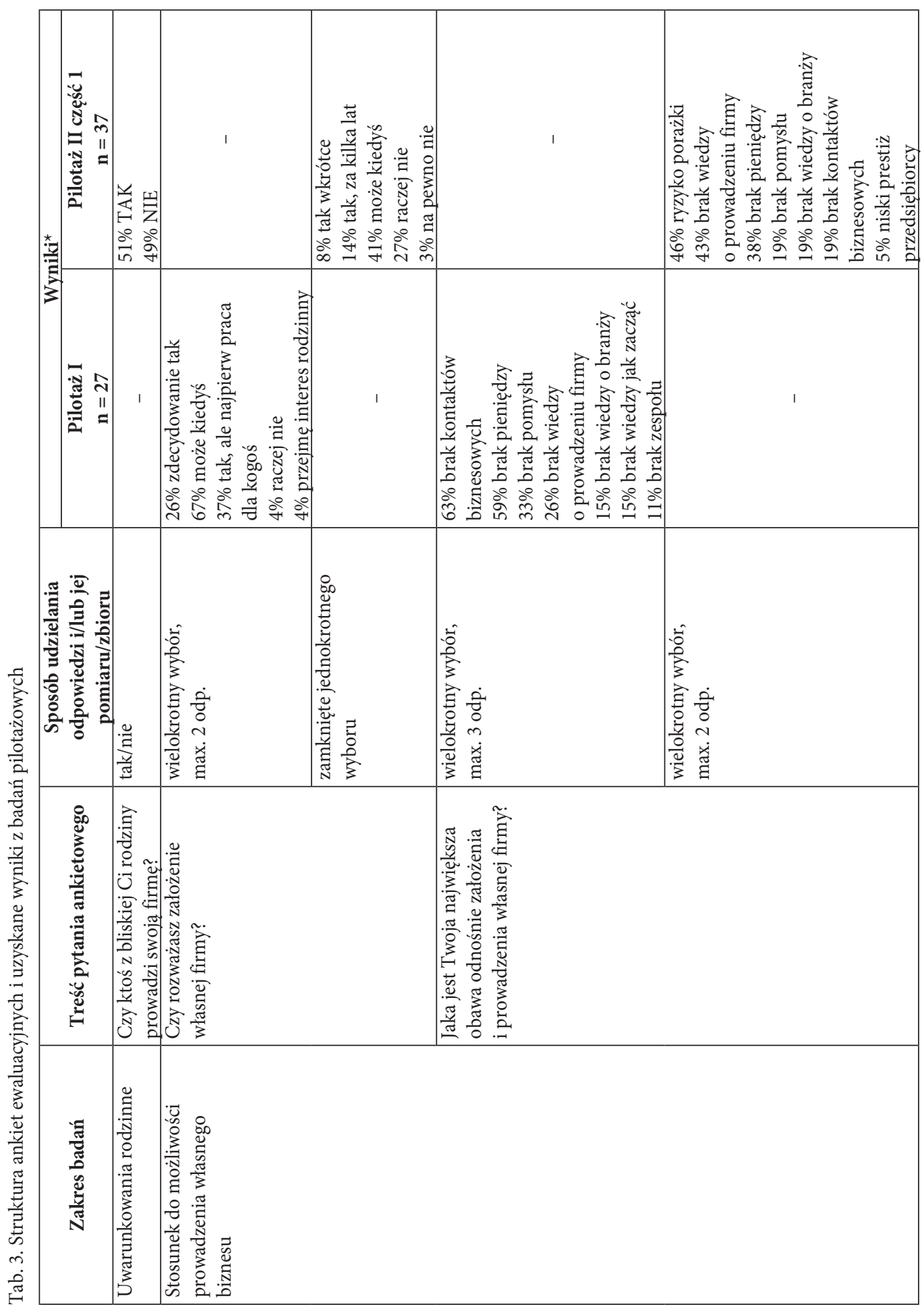




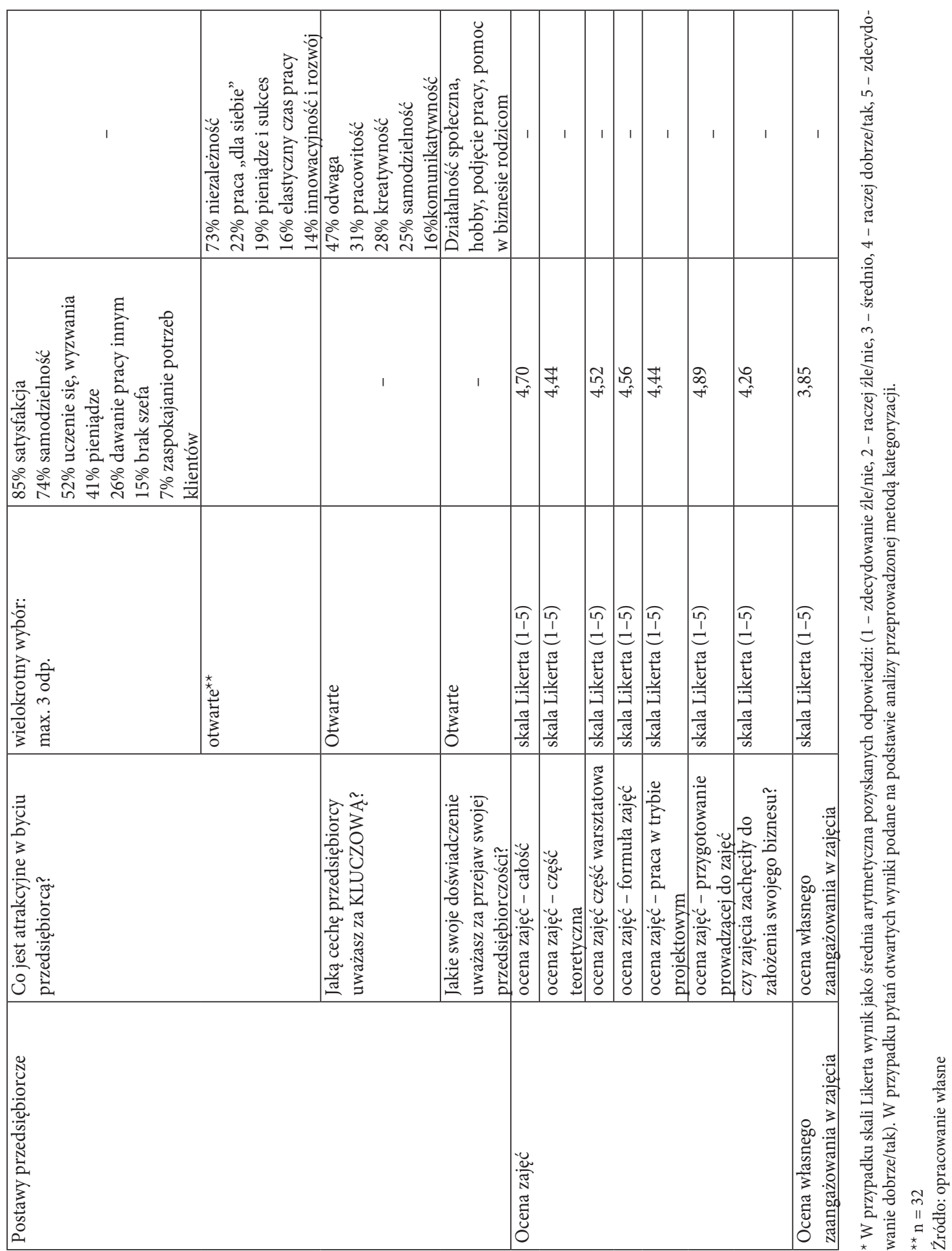


Ryc. 2. Struktura odpowiedzi na pytanie o atrakcyjność bycia przedsiębiorcą

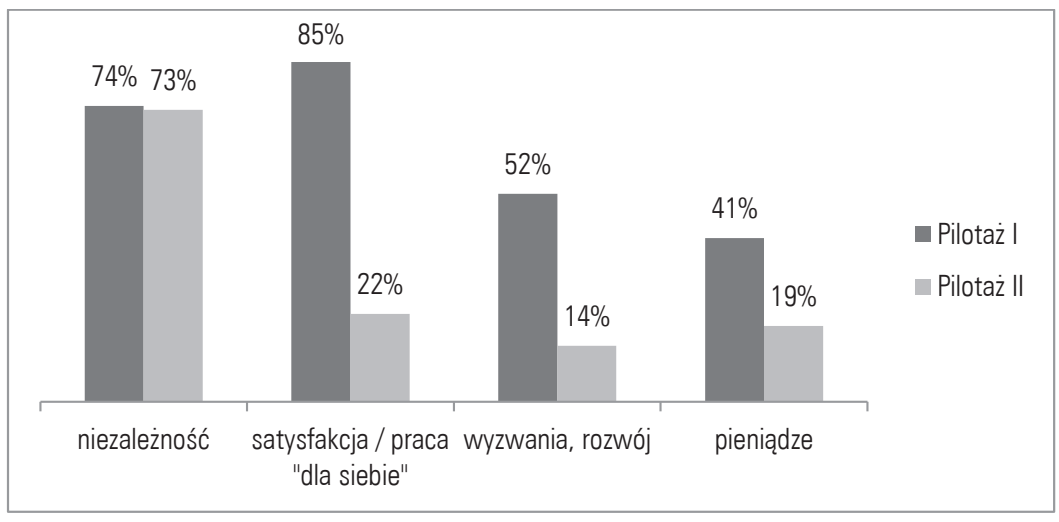

Źródło: opracowanie własne

\section{Podsumowanie}

Od około dekady podejmowane są w Polsce inicjatywy edukacyjne w zakresie nauczania przedsiębiorczości, także na uczelniach wyższych (w tym technicznych). W literaturze przedmiotu edukacja przedsiębiorczości jest tematem dobrze rozpoznanym, zwłaszcza pod kątem jej wpływu na wskaźniki makroekonomiczne, a także względem projektowania programów dydaktycznych. Trzeba w tym miejscu podkreślić, że najnowsze publikacje wyraźnie rozdzielają badania nad przedsiębiorczością w sensie samozatrudnienia od studiów nad postawami prowadzącymi do powstawania ambitnych, szybko rosnących (high-growing), innowacyjnych i przełomowych (disruptive) przedsięwzięć, realizowanych również w ramach większych organizacji. Istnieje luka w wiedzy o efektywności programów edukacyjnych w zakresie przedsiębiorczości. Badania takie są wyzwaniem poznawczym, a zwłaszcza metodycznym, ponieważ efekty tej edukacji następują najwcześniej po kilku, a przeważnie dopiero po kilkunastu latach, należy je więc przeprowadzać z odpowiednim odroczeniem w czasie. Ponadto postawy przedsiębiorcze, zwłaszcza te najambitniejsze, przejawiają się w różny sposób, a więc metoda badawcza powinna tę różnorodność uwzględniać. W krótszym okresie tylko pojedyncze przypadki prób biznesowych podejmowanych przez absolwentów tuż po zakończeniu studiów dają możliwość szybkiej weryfikacji przekazanej wiedzy i umiejętności. Wyniki przeprowadzonych badań pilotażowych pozwoliły wstępnie określić strukturę takiego badania i brzmienie pytań oraz sugerowanych odpowiedzi. $\mathrm{Na}$ obecnym etapie badań planowana ankieta jest trzystopniowa (przed zajęciami, po zajęciach i po 3-5 latach od zakończenia programu) i dzieli się na: ocenę zajęć, badanie stosunku do samozatrudnienia, ocenę szans i zagrożeń związanych z prowadzeniem firmy oraz określenie uwarunkowań rodzinnych. Z pewnością brakuje jeszcze sposobu na uchwycenie efektów w postaci inicjatyw ambitnych, szczególnie cennych. Tropem są tutaj pozyskane odpowiedzi na otwarte pytanie o przykłady przejawów przedsiębiorczości u studentów, niemniej ten element badań wymaga jeszcze dopracowania. Obiecującym kierunkiem prac może być mocniejsze oparcie struktury kwestionariusza na teorii planowanego zachowania (Ajzen, 1991; 2002; 2005), która przewiduje strukturyzację pytań 
w funkcji przekonań: behawioralnych, normatywnych oraz kontrolnych. Głównym celem dalszych badań jest stworzenie i przetestowanie autorskiego kwestionariusza umożliwiającego weryfikację programu edukacyjnego w zakresie przedsiębiorczości i stanowiącego podstawę dla przeprowadzenia długoletnich, porównywalnych badań w tym zakresie. Wyniki takich analiz byłyby cenne w kontekście zapewnienia edukacji przedsiębiorczości odpowiednich standardów, z korzyścią zarówno dla studentów, jak i dla edukatorów. Głębsza wiedza o mechanizmach zachodzących między metodami edukacyjnymi a postawami przedsiębiorczymi mogłaby też wpłynąć na nobilitację edukacji przedsiębiorczości jako ważnego, a niezbędnego, elementu kształcenia na poziomie wyższym.

Pozyskane w artykule wyniki nie uprawniają na tym etapie badań do wnioskowania o efektywności programów edukacyjnych jako takich, a nawet konkretnie takich, jakie odbywają się w omówionej w artykule formie, co sygnalizuje tytuł pracy „komunikat z badań”. Autorka ma świadomość, że o końcowe wnioski będzie się można pokusić po wielokrotnie dłuższym okresie wykonywania i rejestrowania badań, kiedy będzie można zauważyć zarówno ewentualne zmiany w strukturze odpowiedzi, jak i sensu nabierze badanie faktycznych ścieżek kariery absolwentów tych programów. Konieczne jest przy tym obranie do badań równoległej próby kontrolnej tak, aby móc porównać dane. Równocześnie pozyskiwane na bieżąco wyniki badań dotyczące np. obaw związanych ze ścieżką przedsiębiorczą, mogą służyć za wskazówki dla podnoszenia jakości programów edukacyjnych. Występuje więc „sprzężenie zwrotne” między planowaniem, realizacją a badaniem (ewaluacją, weryfikacją) programów edukacyjnych (ryc. 3).

Ryc. 3. Sprzężenie zwrotne występujące między projektowaniem, realizacją a ewaluacją programów edukacyjnych

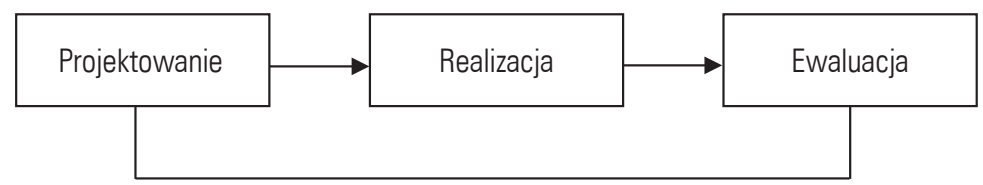

Źródło: opracowanie własne

Literatura

References

Ajzen, I. (1991). The theory of planned behavior. Organizational behavior and human decision processes, 50(2), 179-211.

Ajzen, I. (2002). Constructing a TPB questionnaire: Conceptual and methodological considerations. Pozyskano z: http://chuang.epage.au.edu.tw/ezfiles/168/1168/attach/20/pta_41176_7688352_57138.pdf

Ajzen, I. (2005). Attitudes, personality, and behavior. McGraw-Hill Education (UK).

Blank, S. (2013). Why the lean start-up changes everything. Harvard Business Review, 91(5), 63-72.

Blank, S., Dorf, B. (2012). The startup owner's manual. K\&S; Ranch.

Charney, A., Libecap, G. D. (2000). Impact of entrepreneurship education. Kansas City, MO: Kauffman Center for Entrepreneurial Leadership.

Cieślik, J. (2008). Ksztatcenie w zakresie przedsiębiorczości na poziomie akademickim. Pozyskano z: http://www.fundacja.edu.pl/przedsiebiorczosc/_referaty/sesja_IIa/5.pdf

Cieślik, J. (2014a). Iluzje innowacyjnej przedsiębiorczości. Kwartalnik Nauk o Przedsiębiorstwie, 3, 4-16.

Cieślik, J. (2014b). Przedsiębiorczość, polityka, rozwój. Wydawnictwo Akademickie SEDNO, Warszawa. 
Cieślik, J., Guliński J., Matusiak K., Skala-Poźniak A. (2011). Edukacja dla przedsiębiorczości akademickiej. Polska Agencja Rozwoju Przedsiębiorczości.

Cohen, L., Manion, L., Morrison, K. (2010). A guide to teaching practice. Routledge.

Enfield, J. (2013). Looking at the impact of the flipped classroom model of instruction on undergraduate multimedia students at CSUN. TechTrends, 57(6), 14-27.

Fairlie, R., Robb, A. (2007). Families, Human Capital, and Small Business: Evidence from the Characteristics of Business Owners Survey. Industrial and Labor Relations Review, 60(2), 225-245.

Fayolle, A., Lassas-Clerc, N. (2006, September). Essay on the nature of entrepreneurship education. In International Conference Entrepreneurship in United Europe-Challenges and Opportunities.

Feliniak, U. (2007). Przygotowanie absolwentów szkół do kariery zawodowej. Acta Universitatis Lodziensis. Folia Oeconomica, 210, 85-106.

Gabała, J. (2005). Kształtowanie postaw przedsiębiorczych uczniów. Przedsiębiorczość - Edukacja, 1, $145-152$.

Gaweł, A., Pietrzykowski, M. (2015). Edukacja przedsiębiorczości w postrzeganiu przedsiębiorczości i kształtowaniu intencji przedsiębiorczych. Problemy Zarządzania, 13, 1(51), t. 2. 41-55.

Gibb, A.A. (1993). Enterprise culture and education understanding enterprise education and its links with small business, entrepreneurship and wider educational goals. International small business journal, 11(3), 11-34.

Guzman, J., Liñán, F. (2005; 2015, 10 maja). Perspectives On Entrepreneurial Education: A Us-Europe Comparison. Jean Monnet European Studies Centre Universidad Antonio de Nebrija. Pozyskano z: http://www.nebrija.com/jeanmonnet/pdf/guzman-linian.pdf

Henrekson, M., Sanandaji, T. (2014). Small business activity does not measure entrepreneurship. Proceedings of the National Academy of Sciences, 111(5), 1760-1765.

Herreid, C. F., Schiller, N.A. (2013). Case studies and the flipped classroom. Journal of College Science Teaching, 42(5), 6-66.

Jeruszka. U. (red.) (2001). Metody badania losów i karier absolwentów szkól zawodowych. Warszawa: IPiSS.

Jeruszka. U. (2006). Metody badania jakości kształcenia w szkołach wyższych. Polityka Społeczna, 8.

Jeruszka. U. (2011). Efektywność kształcenia w szkołach wyższych. Polityka Społeczna, 1.

Kuckertz, A, (2013). Entrepreneurship Education - Status Quo and Prospective Developments. Journal of Entrepreneurship Education, 16. 59-71. Pozyskano z: http://ssrn.com/abstract=1862295; http:// dx.doi.org/10.2139/ssrn.1862295

Kuckertz, A. (2013; 2015, 10 maja). What's Hot in Entrepreneurship Research in 2013? The $1^{\text {st }}$ of a Series of Annual Trend Surveys. Universität Hohenheim, Hohenheim, Niemcy. Pozyskano z: https://entrepreneurship.uni-hohenheim.de/uploads/media/What_s_hot_in_Entrepreneurship_ Research_2013_03.pdf

Kuratko, D.F. (2005). The emergence of entrepreneurship education: Development, trends, and challenges. Entrepreneurship theory and practice, 29(5), 577-598.

Liñán, F. (2007). The role of entrepreneurship education in the entrepreneurial process. Handbook of Research in Entrepreneurship Education, 230.

Marszałek, A. (2012). Analiza postaw przedsiębiorczych wśród studentów. E-mentor, 3(45), 25-34.

Osterwalder, A., Pigneur, Y. (2010). Business model generation: a handbook for visionaries, game changers, and challengers. John Wiley \& Sons.

Piróg, D. (2014). Uwarunkowania przedsiębiorczości absolwentów szkół wyższych: założenia teoretyczne i stan rzeczywisty. Przedsiębiorczość - Edukacja, 10, 306-315.

Piróg, D. (2015) Kompetencje z zakresu przedsiębiorczości: rozważania teoretyczne i ich ilustracje w obszarze szkolnictwa wyższego. Przedsiębiorczość - Edukacja, 11, 364-376.

Reis, E. (2011). The Lean Startup. New York: Crown Business.

Richert-Kaźmierska, A. (2011). Przedsiębiorczość jako przedmiot nauczania na wyższej uczelni - wyzwania merytoryczne i metodyczne. E-mentor, 2, 39. 
Rubacha, K. (2013). Standardy badań społecznych. Problematyzowanie praktyki edukacyjnej. Przegląd Badań Edukacyjnych, 1(16), 43-51.

Skala, A. (2015). Przedsiębiorczość - wyzwanie dla edukacji. W: Pustuła, A., Majczyk, J., Darecki, M. (red). Przedsiębiorczość: jednostka, organizacja, kontekst. Warszawa: Wydawnictwo Naukowe Wydziału Zarządzania Uniwersytetu Warszawskiego, 7-27.

Strykowski, W. (1997). Problematyka badawcza technologii kształcenia. Neodidagmata XXIII, 31-41.

Wach, K. (2013). Edukacja na rzecz przedsiębiorczości wobec współczesnych wyzwań cywilizacyjno-gospodarczych. Przedsiębiorczość - Edukacja, 9, 246-257.

Zioło, Z. (2012). Miejsce przedsiębiorczości w edukacji. Przedsiębiorczość - Edukacja, 8, 10-23.

Agnieszka Skala, dr, Politechnika Warszawska. Doktor nauk ekonomicznych, absolwentka SGH, adiunkt na Politechnice Warszawskiej, współzałożycielka Szkoły Przedsiębiorczości Innovation Nest SPIN. Prowadzi zajęcia z przedsiębiorczości w Politechnice Warszawskiej i Akademii Leona Koźmińskiego. Pracuje naukowo w obszarze przedsiębiorczości wysokiej techniki i gospodarki cyfrowej oraz edukacji przedsiębiorczości. Członek Rady Programowej Fundacji Startup Poland. Absolwentka pierwszej edycji Lean LaunchPad Educators Program na Uniwersytecie Kalifornijskim w Berkeley. Organizatorka pierwszej edycji Startup Weekend NEXT w Polsce. Autorka case studies o polskich startupach w branży e-biznesu. Wspiera wartościowe inicjatywy edukacyjne na styku nauki, techniki i biznesu w Polsce.

Agnieszka Skala, $\mathrm{PhD}$, graduate in economics at the Warsaw School of Economics, Assistant Professor at the Warsaw University of Technology, co-founder and CEO of Innovation Nest Entrepreneurship School (SPIN). Researcher in the area of high-technology entrepreneurship, e-business environment and entrepreneurship education. Member of the Academic Network of Entrepreneurship Educators SEIPA, EFER Alumni and graduate from Lean LaunchPad Educators Program at University of Berkeley in 2012. Author of case studies of Polish e-business startups, organizer of the first edition of Startup Weekend NEXT in Poland (2012). She supports science-business-technology initiatives in Poland.

\section{Adres/Address:}

Politechnika Warszawska

Wydział Transportu

ul. Koszykowa 75

00-662 Warszawa, Polska

e-mail: askala@wt.pw.edu.pl 